\title{
OPERATIONAL INDICATORS OF THE LEARNING MANAGEMENT SYSTEM IN VIRTUAL SPACES SUPPORTED BY ICT
}

\author{
Dr. Jose CAPACHO \\ ORCID: 0000-0002-9529-1327 \\ Deparment of Systems Engineering and Computer Science \\ Universidad del Norte \\ Barranquilla, Colombia \\ Dr. Miguel JIMENO \\ ORCID: 0000-0001-5398-7070 \\ Deparment of Systems Engineering and Computer Science \\ Universidad del Norte \\ Barranquilla, Colombia \\ Augusto SALAZAR \\ ORCID: 0000-0002-1063-7561 \\ Deparment of Systems Engineering and Computer Science \\ Universidad del Norte \\ Barranquilla, Colombia
}

Received: 05/08/2018 Accepted: 02/11/2018

\begin{abstract}
The paper presents the conceptual framework and operational indicators of the Learning Management System in virtual spaces supported by ICT. The framework of the management system has three layers that are operational, management-operative, and management-decision. The conceptual foundation of the system is related to the Science of Education, the Science of Computing and the Science of Administration, and takes into account the representative model of the teaching-learning process of the student in virtual spaces supported by ICT. The dimensions, characteristics, variables, and indicators of the management system are assembled on the model in question. The indicators presented in the article correspond to 153 indicators of the operational layer. These were evaluated internationally with a confidence level of more than $90 \%$. The operative indicators are contained in the dimensions of identification, academic, pedagogical-didactic, formative, of assessment of the virtual learning, and technological of the system of management of the virtual learning. The importance of the indicators presented ensures the success of the operational phase of the management system. Therefore, once the operation of the system is guaranteed, the success of the management-operative and management-decision layers of the system is assured. The correct fulfillment of the layers above guarantees the achievement of both the student's learning in the virtual course and the institution that offers virtual teaching through virtual learning platforms supported by ICT.
\end{abstract}

Key words: LMS with ICT, operation-management-decision in eLearning, operative indicators, virtual learning. 


\section{INTRODUCTION}

Virtual education is fundamental in the framework of an informational and global society. The preparation of human talent in a globalized society with a high research component is based on the socio-technical paradigm of the network society (Castells, 2004). The current society (2018) must ensure both the preparation of human talent for the network and take into account the risks and trends of a computerized society with a future horizon (Masera \& Ortiz, 2018). The great responsibility of online, asynchronous, remote, and multilingual training supported by ICT must integrate international influence with local content (Mittelmeier, Rienties, Tempelaar, Hillaire, \& Whitelock, 2018) to ensure eLearning from the student. The integration of the Science of Education, of the Computer Science, and the Administrative Science offer the necessary foundations to achieve the construction of a virtual learning management system. The science of education brings pedagogical and didactic approaches to the virtual teaching-learning process (Scherer, Tondeur, Siddiq, \& Baran, 2018). Computer science provides the foundations of Algorithm and Software Engineering, to achieve the functioning of eLearning platforms (Garcia, Falkner, \& Vivian, 2018), based on large volumes of data (Chitu, Cernian, \& Sgarciu, 2018) updated in real time. The administrative science supports the processes of registration, teaching-learning, assessment, and evaluation of virtual learning (Martin \& Kumar, 2018), and is the basis for integrating the operational, management and decision phases within the management system of virtual learning (Cheawjindakarn, Suwannatthachote, $\&$ Theeraroungchaisri, nd). It is of the greatest importance to relate that within the framework of a current society generating new knowledge is virtual education which provides the greatest degree of flexibility in times, spaces, languages, content, and administrative processes. Then, based on the above, the system of management indicators of learning in its operative administrative and decision-management layers has to work in an integrated way within the virtual course and integrated through the course with the operation of the Virtual Education Institution ( VEI ).

\section{LITERATURE REVIEW}

The theoretical review of the basic foundations to build the system of management indicators takes into account i) Virtual class indicators. ii) Representative frameworks to evaluate virtual learning. iii) The models for the evaluation of learning in ICT. iv) Quality assurance systems in virtual education in the countries. v) The systems of standards and accreditation nationally and internationally in virtual education.

\section{Virtual Class Indicators}

Indicators of evaluation of online courses taking into account the continuous strategies of professional development (Perez-Foguet et al., 2018). These qualitative and quantitative indicators first assess the perception of the quality and relevance of teaching and second, the acquisition of student learning. Taking into account the modality of blended learning, the core elements of computational thinking are presented based on the learning environment and analyzing the impact of pre-university courses in institutions, teachers, and students (Basogain, Olabe, Olabe, \& Rico, 2018 ). The quality of the academic courses in virtual education is evaluated through the instructional, communicative aspects, development of the course, and learning experiences based on the activities and perceptions of the students (Soffer, Kahan, \& Livne, 2017). Analysis of commitment and persistence of the learning of the students in mass open courses in line (massive open online courses (MOOCs)). This analysis models the relationship between academic selfefficacy, teaching, utility, ease of use, commitment to learning and persistence in MOOCs (Jung \& Lee, 2018), reaching the conclusion of the direct relationship that exists between self-study, the presence of the teacher, and the usefulness of the course with the commitment in the learning of the virtual student. The creation of 37 quality indicators to be applied to postgraduate courses in virtual medical education is a theoretical construct that applied the Delphi procedure to determine the consensus of the aforementioned indicators (de Leeuw, Walsh, Westerman, \& Scheele, 2018). 


\section{Frameworks to Evaluate Virtual Education}

The evaluation framework in the eLearning of courses and programs identifies seven elements that are institutional support, technological infrastructure, course design, support of instruction and learning, effectiveness of learning, satisfaction of students and teachers, and assessment of the virtual class and evaluation (Martin \& Kumar, 2018), in order to ensure the quality of virtual education. In the framework of massive open online courses (MOOCs) platforms, criteria were identified to increase the commitment of students in their virtual learning process based on personal expectations, preferences and cognitive learning style (Assami , Daoudi, \& Ajhoun, 2018). The dimensions of virtual teacher, course, technology, design, and environment in eLearning were identified in the framework as keys to improve the satisfaction of students in virtual classes (Asoodar, Vaezi, \& Izanloo, 2016). Based on the challenges and opportunities of open and online education (OOE) applied to higher education institutions, the core concepts of education (OOE) were identified within which are "online teaching, support, assessment, external groups, flexibility, quality in education, reputation of the institution, and educational efficiency "(Schophuizen, Kreijns, Stoyanov, \& Kalz, 2018).

\section{Models to Evaluate Virtual Education}

The model that aims to align the competencies with the learning activities to comply with the design of an e-assessment process (Guerrero-Roldán \& Noguera, 2018), is based on the potential of the technology and has in account the formative approach of evaluation of virtual student learning. Based on the evaluative dimensions of quality in eLearning, a comparative analysis of 25 models and 42 dimensions of evaluation of virtual learning is carried out, reaching the conclusion that the institution, the technology, the student, the teacher, the pedagogy, and the evaluation of the development of the virtual course are the essential dimensions of the quality of virtual education based on ICT (Marciniak \& Sallán, 2018). The quality of the virtual and hybrid education processes (virtual and face-to-face) is validated through the use of 74 quality indicators which are analyzed based on the success factors of "credibility, access, transparency, flexibility, interactivity , personalization, and productivity "(Blieck et al., 2018) of the virtual course course.

\section{Quality Assurance Systems in Virtual Education}

The quality assurance of massive open online courses (MOOCs) is done using data mining and semantic analysis in the areas of software, science, and administration (Cohen \& Holstein, 2018). The quality assurance (QA) of the virtual courses is represented by a set of processes that are author content, course development, teacher recruitment, pedagogy, and online course content (Chua \& Lam, 2007). This research concludes that the four important characteristics in the quality of virtual courses are teachers, exercises, learning atmosphere, and workload. The use of the Technolgy Enhancement Learning (TEL) concept, based on 24 research articles, ensures the quality of the students' learning outcomes, the teaching experience, and the assessment methods in their improvement when the students use them for their technological media learning (Tawafak, Romli, bin Abdullah Arshah, \& Almaroof, 2018). The evaluation of the quality of the online courses in the United States is represented by standards related to the structure of the virtual course, the technology used in the student's learning, and the characteristics of communication to achieve discussion and interaction in the online course (Aldridge \& Parker, 2018).

\section{Standardization and Accreditation Systems}

One of the most complete studies in designing eLearning quality indicators is contained in the "Handbook on Quality and Standardization in E-Learning" (Ehlers \& Pawlowski, 2006), which contains the concept of quality of virtual education in its methods and approaches, the standards in E-Learning which is complemented by fields of practice and case studies. The Handbook contains the educational quality standards in eLearning related to the ISO / IEC 19736-1 standard relating the Quality Adaptation Model (QAM) which is adapted to the standard. The use of immersive learning environments for eLearning and evaluation of medical students allows for formative assessment mechanisms within the framework of the 
"Accreditation Council for Graduate Medical Education (ACGME)" (McGrath et al., 2018). Based on the best practices approach, technology, faculty, administration, curricular structure, and support are considered as the necessary elements in the framework of online program accreditation processes (Bergeron \& Fornero, 2018).

\section{THEORETICAL FOUNDATION OF THE OPERATIONAL INDICATORS OF THE LEARNING MANAGEMENT SYSTEM IN VIRTUAL SPACES}

The theoretical foundation of the indicators of the operational layer of the learning management system in virtual spaces takes into account the conceptual review of the literature as a basis to ensure the teachinglearning process in virtual education. In this sense, the indicators, frameworks, models, quality systems, and the guidelines and systems of accreditation in virtual spaces supported by ICT are taken into account as foundations. The review of the aforementioned literature is integrated into the representative model of the training process in virtual spaces supported by ICT shown in Figure No. 1 (Capacho, 2015) taking into account the science of education, computer science, and finally the administrative science applied to eLearning.

The model consists of 14 steps that are: 1 . Construction of the virtual course, for which it is of the utmost importance to take into account the national and international standards for the construction of virtual courses such as IMS, LOM in order to incorporate the construction of the course the latest tools and insights of instructional design (Yago, Clemente, Rodriguez, \& Fernandez-de-Cordoba, 2018), (Pástor, Jimenez, Gomez, \& Isotani, 2018). 2. Organization and administration of the virtual curriculum, is the design of curricular structures (by subjects, by projects, formal, or informal) based on virtual courses. This step identifies the future vision of the Virtual University (Tait, 2018), with the purpose of fulfilling periods of the transformation of university education models to open, online, international, multilingual and distance educational models (Marshall \& Flutey, 2018), in order to empower virtual education (Bordoloi, 2018). 3. The profiles of training (by competences, professionals, or business) are essential to the success of the virtual curriculums, in order to identify and evaluate the educational sufficiency with which the student is virtually assured by a correct assessment (Sarafzade, Bishop, Nagle, Tilden, \& Oettinger, 2018), in order to achieve the correct professional profiles (Martins, de Menezes, Lima Terçariol, Gitahy, \& Ikeshoji, 2018) and occupational (Heinen \& Peeters, 2018) of the student at service of the information society. 4 . The pedagogical approach (behaviorism, constructivism, constructionism) is important because it becomes the educational foundation of the virtual course, with a view to achieving a sustainable development (Thorne \& Macgregor, 2018), with bases in collaborative learning (Rodriguez, Hudson, \& Niblock, 2018) and using learning objects that have "smart" characteristics (Ahn et al., 2018) to make the student's learning process easier. 5. The definition of virtual training objectives implies the use of approaches for the design of instructional level objectives (Bloom, Gagñe, etc ...) in order to design quality objectives (Outlaw, Rice, $\&$ Wright, 2018) located in the context of a global virtual education that takes into account the current communication tools of the net generation (Pellas, Kazanidis, \& Fotaris, 2018) (Zheng, Chen, \& Burgos, 2018). 6. The pedagogy and the objectives of virtual learning are bases for the design of didactics as a virtual teaching strategy to use peer interaction processes in online courses playing the role of e-Tutor during group activities (Sansone, Ligorio, \& Buglass, 2018), or definition of didactic approaches integrated between contents - learning objectives - training profiles where during the development of the virtual course repetitive didactic cycles are applied to the actions of interaction, feedback, and assessment of virtual learning (Stracke \& Tan, 2018). 7. The integrated virtual teaching-learning process or the application of the didactic in the virtual course, step in which the integration of the communicative process between professors and students at a virtual level is validated (Soler \& Sarsa, 2012). 8. Assessment of the student's learning process, the point at which both the fulfillment of the learning objectives within the framework of the pedagogy used and the correct integration of the states of the virtual learning process are validated 9. Evaluation of the learning results, This requires an integration between the Virtual Education Institution (VEI) and the industry in order to project to step 12., which means actions of transformation of traditional companies to digital businesses (Nissen \& Seifert, 2018) using collaborative actions, large databases, remote statistical analysis, virtual assistance and evaluation, distribution of information results, to arrive at the administration of online knowledge databases. 10. Evaluation of the operation process of the technological platform, which represents 
the basis of the Science of Computing in its software, hardware and electronic communication integration processes through the network (Ouadoud, Chkouri, \& Nejjari, 2018), ( Uziak, Oladiran, Lorencowicz, \& Becker, 2018), (Porras, Alcántara-Manzanares, \& García, 2018). 11. Once the virtual course has been operated, the model leads to a process of continuous improvement of the virtual course to consolidate in the virtual curriculum an administrative process of total quality corresponding to Administrative Science (Aziz, Mahmood, \& Bano, 2018). 12. Integration of the virtual student to the professional life within the productive apparatus of the companies (Hamalainen, Lanz, \& Koskinen, 2018) to comply with the next step. 13. Evaluate the professional performance of virtual graduates (McLoughlin, Patel, O'Callaghan, \& Reeves, 2018), at which point virtual curriculum compliance is validated to achieve the last step to be followed. 14. Satisfy the needs of society regarding virtual education (Jackson, 2018).

It is of the utmost importance to emphasize that the representative model of the training process in virtual spaces (Figure No. 1) has the following characteristics: i) In the development of the process, the science of education, the science of computerization and administrative science are integrated. ii) The model is re-fed or closed-loop, which means that from any part of the model it is possible to return to previous steps and the final step (14.) or once the needs of society are identified, it is returned to the first (1.) step in terms of the continued redesign of the virtual course. iii) The operational indicators (Ii, $1<=\mathrm{i}<=153$ ) are distributed throughout the process, and are integrated into a set of dimensions, characteristics, and variables in order to explicitly identify the operation indicators in the framework of the learning management system in virtual spaces supported by ICT, which will be developed below.

\section{INTEGRATION OF THE OPERATIONAL INDICATORS IN THE REPRESENTATIVE MODEL OF THE VIRTUAL SPACES TRAINING PROCESS}

The integration of operational indicators in the representative model of the training process in virtual spaces requires a conceptual structure composed of dimensions, characteristics, variables and finally representative indicators of eLearning. Then from the general (dimensions) to the particular (indicators), the conceptual structure is:

1. Dimensions. The dimensions are systemic components of the online training process, representative of the impact of student learning when going from an initial learning state (Eo) to a final learning state $(\mathrm{Ef})$, within a virtual training environment. The technical dimension of the virtual space and the evaluative dimension of learning are large dimensions of the virtual environment.

The dimensions with their respective processes that are going to be considered in the model are the following:

- Identification dimension of the model.

- Identification process.

- Academic dimension.

- Academic process.

- Pedagogical-didactic dimension.

- Pedagogical process.

- Educational process.

- Formative dimension.

- Ethical dimension.

Ethical process.

- Cognitive dimension.

Cognitive process.

- Affective dimension.

Affective process.

- Communicative dimension.

Communicative process 
- Aesthetic dimension.

Aesthetic process.

- Body dimension.

Body development process,

- Socio-political dimension.

Socio-political development process.

- Evaluative dimension

- Process of evaluation of virtual learning.

- Technological dimension.

- Technological process.

The aforementioned dimensions integrated into the representative model of the formation process are shown in Figure No. 2.

2. Feature. Category representative of the level of quality of online learning achieved by the student, which are grouped into dimensions or factors.

3. Variables: It is a representative set of the learning change achieved by the student when interacting with the activities, resources or components of the virtual environment; change that is valued both in quality and in level (quantitative) of learning.

4. Indicator. It is an empirical reference of the variable, representative of the degree of quality of the learning of the virtual space and to which they can be measured in qualitative or quantitative scales. Within the Technical dimension corresponding to the characteristic "virtual space network services", taking into account the variable "distribution lists", two indicators can be defined that are: nominal scale indicator $=$ The virtual course allows the management of distribution lists ?, or indicator in scale Interval $=$ How many distribution lists does the virtual course handle?

\section{VALIDATION OF THE CONCEPTUAL STRUCTURE OF THE MODEL}

The validation of the integrated conceptual structure (Figure No. 2) (Capacho, Jimeno \& Salazar, 2018) was carried out in two phases, the first manual and the second computerized. In the manual phase, 33 accounts were carried out and in the computerized phase, 54 accounts for a total of 87 surveys. The surveys were conducted by expert virtual education judges representing the continents of America, Europe, Australia, Asia, and Africa. The manual validation achieved a total of 818 responses, while the computerized validation reached a total of 1207 responses.

Bearing in mind that the number of surveys conducted is greater than $30(87>=30)$, and taking into account that the surveys follow a normal statistical distribution, using a confidence interval of $90 \%$ and an error of $10 \%$, and being $\mathrm{P}$ equal to the proportion of respondents who do not disagree, it was concluded in the manual validation with $\mathrm{n}=33$ that $\mathrm{P}_{\text {Manual }}=(2.09 * 1.645)+86.5359=89.97$. For its part in the computerized validation for a $\mathrm{n}=54$ it was concluded that $\mathrm{P}_{\text {computerized }}=\left(1.17^{*} 1.645\right)+89.9027=91.83$. Therefore, since in both cases the value of the calculated statistic falls within the acceptance region, it is deduced that based on the sample evidence, the initial hypothesis $\mathrm{P}=0.9$ is accepted, justified by the level of confidence initially selected, arriving at the conclusion that the indicators are valid with the participation of international judges.

\section{REPRESENTATIVE SAMPLE OF THE CONCEPTUAL STRUCTURE OF THE MODEL}

The conceptual structure of the model has 6 dimensions, 32 characteristics, 84 variables and 153 indicators is shown partially in Table No. 1. The number of indicators associated with each of the dimensions is Identification 14, Academic 25, Pedagogic 8, Formative 32, Evaluative 38, and Technological 36. Then taking into account the number of indicators accepted by dimension, it is emphasized that the model focuses its strength on the evaluative and formative dimensions with the greatest number of indicators. The evaluation dimension takes into account the assessment of student learning. The formative dimension is related to the teaching-learning process using the eLearning platform, and in this sense, it is this dimension that is responsible for processes through the model of ensuring the quality of virtual education. 


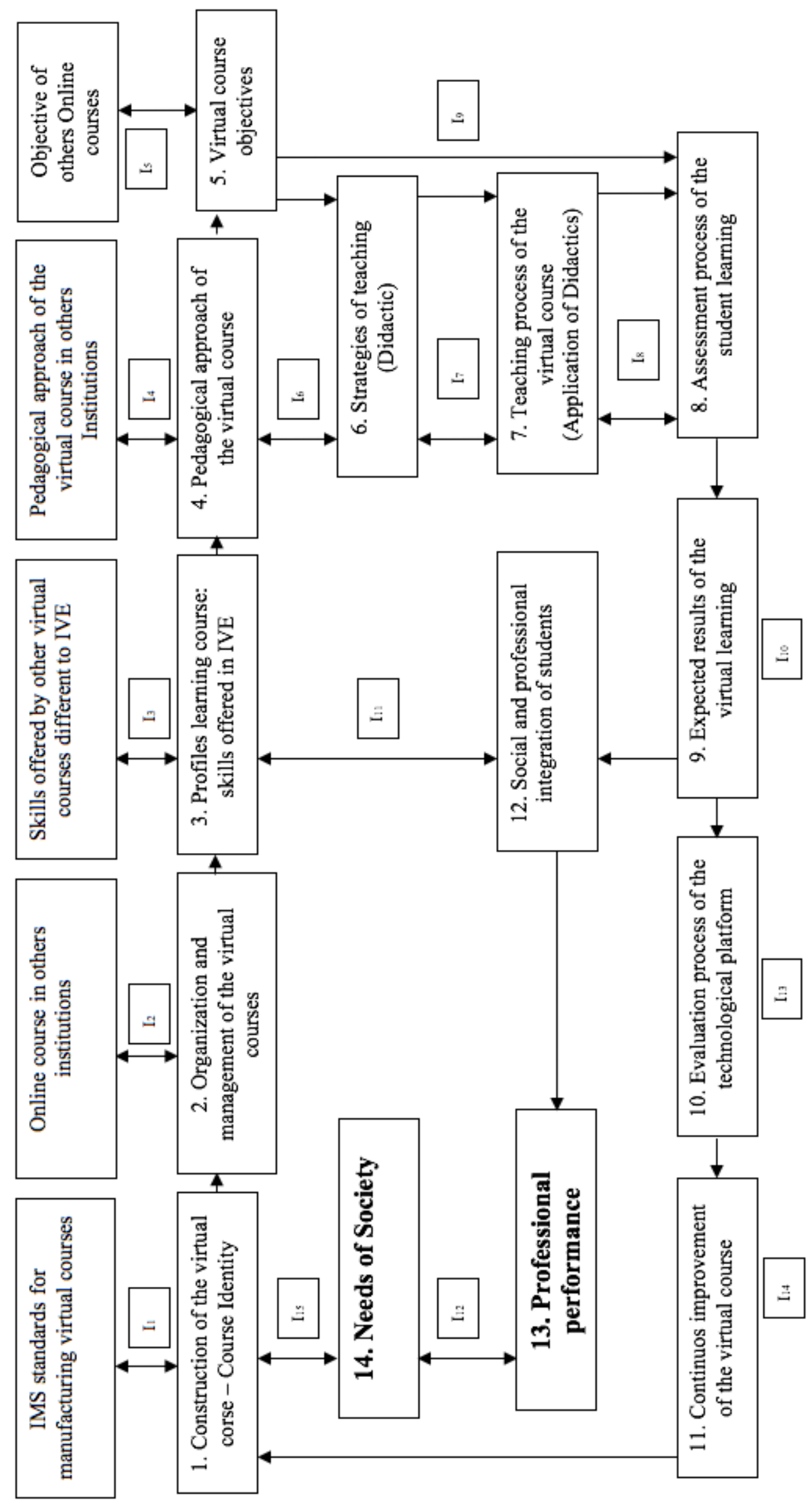

Figure 1. Representative model of the process in virtual spaces supported by ICT. 


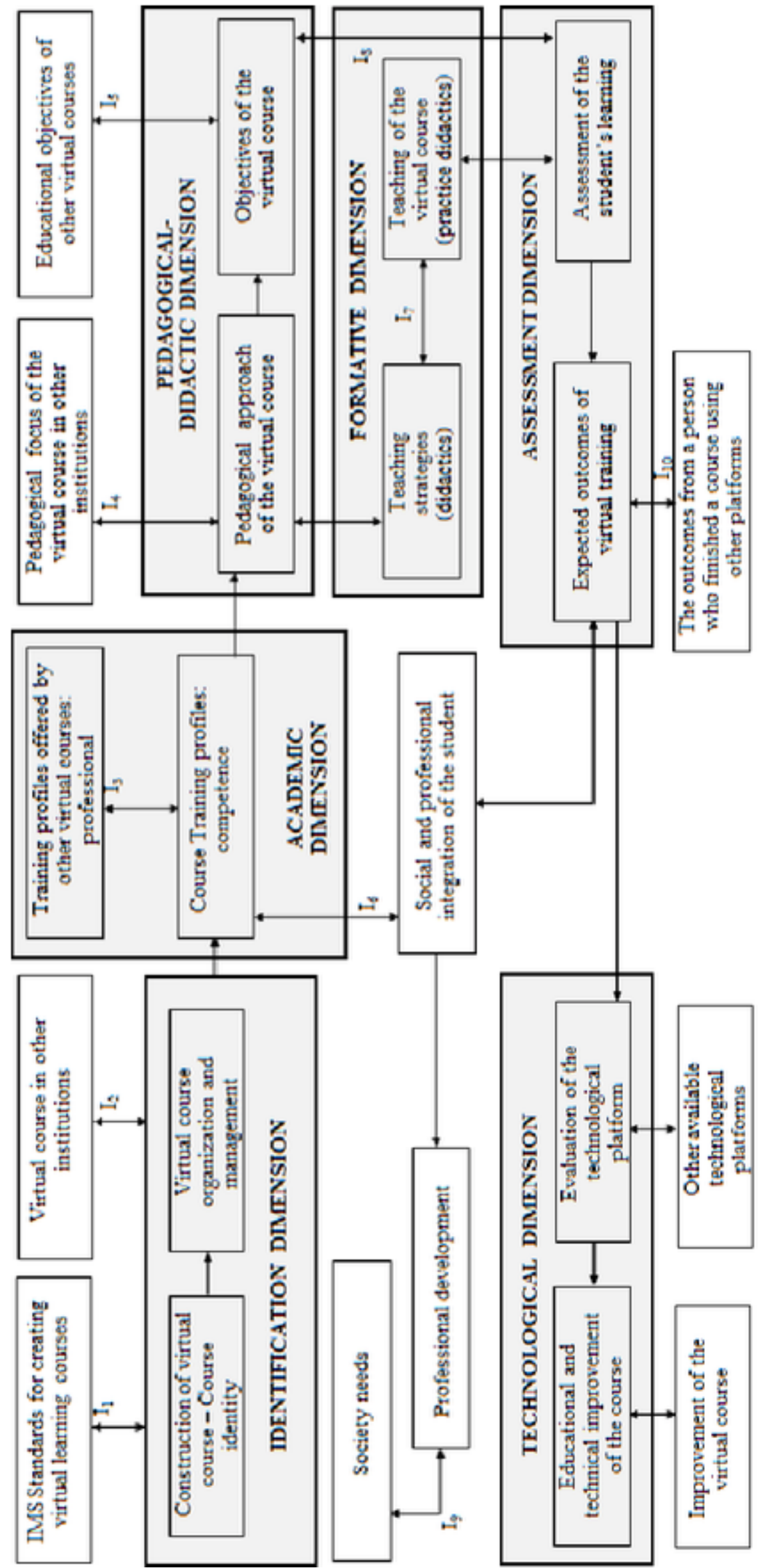

Figure 2. Integrated dimensions to the representative model of the process in virtual spaces supported by ICT. 


\section{OPERATION OF THE OPERATIONAL INDICATORS OF THE LEARNING MANAGEMENT SYSTEM SUPPORTED BY ICT.}

The operation of the operational indicators within the virtual learning management system is represented by the projected computer system representative of the aforementioned indicators (Figure No. 3). The virtual course forms a tree structure. The operational indicators are contained within a tree structure. From the upper branch of the tree to the leaves, this tree is composed of dimensions, characteristics, variables, and indicators. The indicators are at the level of the leaves of the tree.

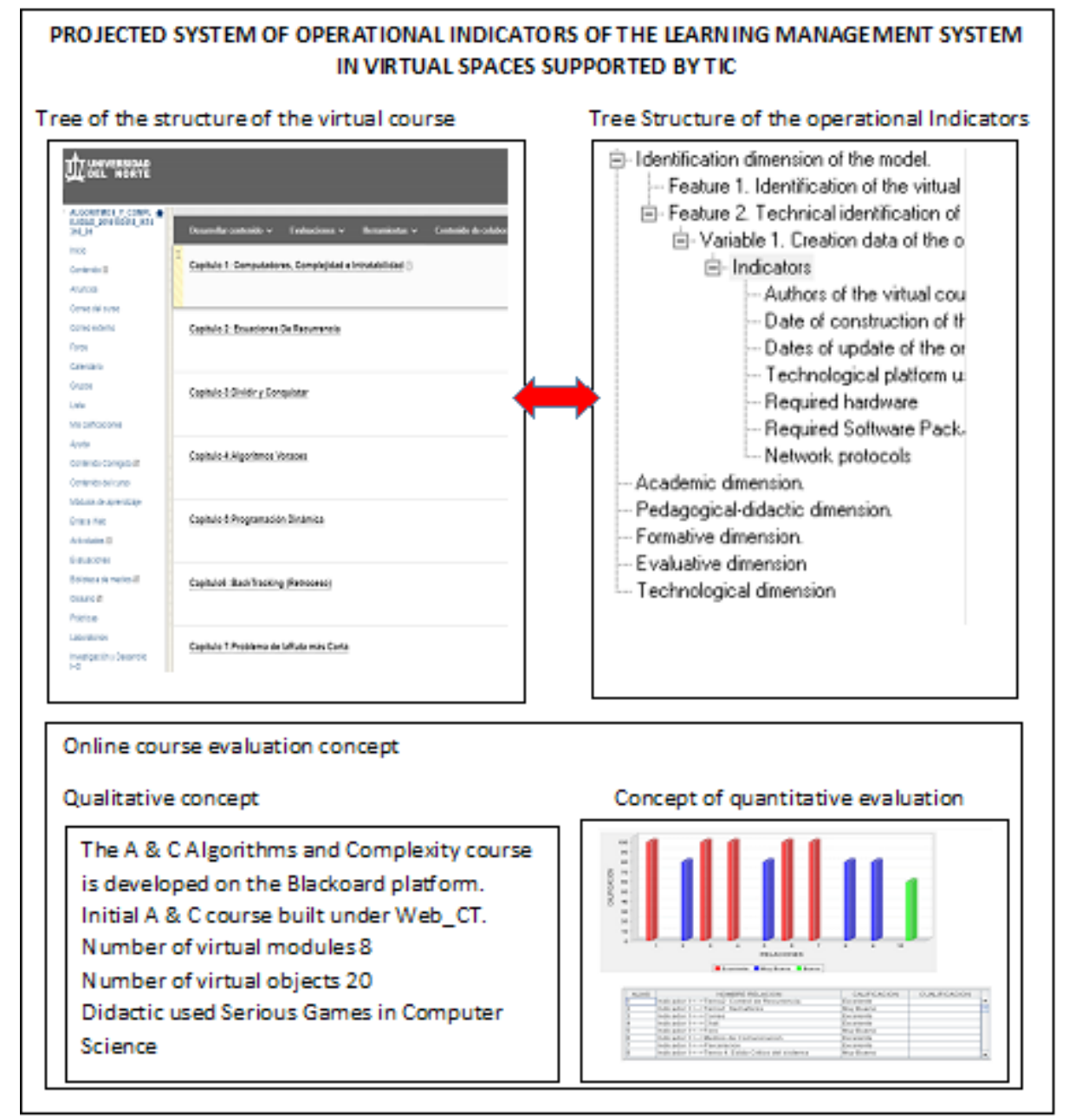

Figure 3. Projected system of operational indicators

The content tree structure of the virtual course (with the name of the course in the root) and its components (Syllabus, virtual content (virtual modules, learning objects), announcements, course mails, external mail, discussions, calendar, groups virtual, distribution lists, discussion forums, virtual tutorials, programming projects, student assessment, calendar, rubric, ..., wikis) is compared with the structure of operational indicators. This comparison is made by an expert judge in virtual education. The judge evaluates the virtual course comparing the operational indicators of the model, with the tree structure of the virtual course. This comparison generates a set of relationships, between the indicators of all the dimensions with the content of the virtual course. The comparison results in an evaluation of the virtual course. This evaluation is done in a qualitative and quantitative way. In the qualitative relationship, the concept of the evaluation of the relationship at a qualified level is placed. This scale makes the course assessment for the indicated ratio, in the scales excellent $[80 ; 100]$, very good $[60 ; 79]$, good $[40 ; 59]$, regular $[20 ; 39]$ and for improvement $[0$; 19 ] Therefore the concept of online course evaluation is both qualitative and quantitative. 
Table 1. Conceptual structure of support for operational indicators of the learning management system in virtual spaces supported by ICT

\begin{tabular}{|c|c|c|c|c|c|}
\hline Identification & Academy & Pedagogical-Didactic & Formative & Evaluative & Technological \\
\hline $\begin{array}{l}\text { Define the identity of } \\
\text { an e-learning course } \\
\text { on their membership } \\
\text { in a virtual education } \\
\text { center. The dimension } \\
\text { contains authors and } \\
\text { actors of the course } \\
\text { with their identifying } \\
\text { characteristics and } \\
\text { conditions of the } \\
\text { intellectual property. }\end{array}$ & $\begin{array}{l}\text { Contains objectives, } \\
\text { teaching methodologies, } \\
\text { curriculum flexibility } \\
\text { of online course and } \\
\text { logistical support } \\
\text { for the achievement } \\
\text { of student training } \\
\text { profiles to interact } \\
\text { with the virtual course; } \\
\text { dimension corresponding } \\
\text { to interactive learner } \\
\text { academic process subject- } \\
\text { object virtual learning. }\end{array}$ & $\begin{array}{l}\text { Contains the } \\
\text { definition of the } \\
\text { components related } \\
\text { to the pedagogical } \\
\text { and didactic } \\
\text { approaches applied in } \\
\text { the virtual course to } \\
\text { achieve the formation } \\
\text { of student profiles } \\
\text { and consequently } \\
\text { their virtual learning. }\end{array}$ & $\begin{array}{l}\text { It contains both the } \\
\text { necessary categories } \\
\text { related to instruction } \\
\text { of students in specific } \\
\text { knowledge, as the } \\
\text { necessary categories for } \\
\text { the student develops all } \\
\text { its features, conditions } \\
\text { and potentials, as a } \\
\text { person looking human } \\
\text { development through a } \\
\text { virtual environment to } \\
\text { serve the society. }\end{array}$ & $\begin{array}{l}\text { The evaluative } \\
\text { dimension meets } \\
\text { the central role of } \\
\text { research objective } \\
\text { assessment of } \\
\text { learning acquired } \\
\text { by the student in } \\
\text { the virtual course; } \\
\text { therefore, the } \\
\text { dimension contains } \\
\text { the essential } \\
\text { components of } \\
\text { the evaluation } \\
\text { process of student } \\
\text { learning in virtual } \\
\text { environments. }\end{array}$ & $\begin{array}{l}\text { The technological } \\
\text { dimension defines } \\
\text { the characteristics } \\
\text { that contain essential } \\
\text { indicators to assess } \\
\text { the construction and } \\
\text { performance of the } \\
\text { platform to support } \\
\text { virtual learning, in } \\
\text { their construction, } \\
\text { hardware, software, } \\
\text { and communications. }\end{array}$ \\
\hline $\begin{array}{l}\text { Feature } 1 \text {. The course } \\
\text { has an identity that } \\
\text { characterizes it as virtual } \\
\text { learning environment } \\
\text { located within an } \\
\text { educational system and } \\
\text { different from others of } \\
\text { its kind. }\end{array}$ & $\begin{array}{l}\text { Feature } 1 . \text { The virtual } \\
\text { course certifies the } \\
\text { training profile of } \\
\text { student knowledge, } \\
\text { methodologies and } \\
\text { basic principles of the } \\
\text { area of knowledge to } \\
\text { which belongs the virtual } \\
\text { environment, and ensures } \\
\text { student learning and } \\
\text { training for a respective } \\
\text { work, taking into account } \\
\text { the progress of both } \\
\text { the subject area of the } \\
\text { course as the Information } \\
\text { Technology and } \\
\text { Communications - ICT. }\end{array}$ & $\begin{array}{l}\text { Feature 1. The virtual } \\
\text { learning environment } \\
\text { used in the process } \\
\text { of student learning } \\
\text { one or multiple } \\
\text { pedagogical } \\
\text { approaches, } \\
\text { considering both } \\
\text { classical pedagogy } \\
\text { and new approaches } \\
\text { to modern pedagogy. }\end{array}$ & $\begin{array}{l}\text { Feature 1. The virtual } \\
\text { course ensures the } \\
\text { development of ethics, } \\
\text { cognitive, emotional, } \\
\text { communicative, aesthetic, } \\
\text { physical and socio- } \\
\text { political dimensions of } \\
\text { the student through } \\
\text { the structuring of } \\
\text { content organized into } \\
\text { thematic units to achieve } \\
\text { comprehensive training } \\
\text { students. }\end{array}$ & $\begin{array}{l}\text { Feature } 1 . \text { The } \\
\text { virtual course } \\
\text { is clear, fair and } \\
\text { universal rules for } \\
\text { assessing student } \\
\text { learning. }\end{array}$ & $\begin{array}{l}\text { Feature } 1 . \text { The virtual } \\
\text { course meets national } \\
\text { / international for } \\
\text { making virtual } \\
\text { learning environments } \\
\text { standards. }\end{array}$ \\
\hline $\begin{array}{l}\text { Variables: Existence } \\
\text { of an educational } \\
\text { institution within which } \\
\text { there is a charge of } \\
\text { creating the academic } \\
\text { unit (department } \\
\text { or program), } \\
\text { administration and } \\
\text { development of an } \\
\text { online course }\end{array}$ & $\begin{array}{l}\text { Variables: } 1 \text {. Clarity of } \\
\text { definition of training } \\
\text { profiles (professional, } \\
\text { occupational, } \\
\text { competencies) that aims } \\
\text { to achieve the virtual } \\
\text { course to develop the } \\
\text { objectives. 2. Clarity of } \\
\text { objectives and goals } \\
\text { of the virtual training } \\
\text { course. 3. Concordance } \\
\text { between the content and } \\
\text { methods of the virtual } \\
\text { environment with the area } \\
\text { of knowledge to which the } \\
\text { virtual course belongs. } 4 . \\
\text { Adequacy of the contents, } \\
\text { methods, and activities } \\
\text { in the virtual classroom } \\
\text { to achieve compliance } \\
\text { with the course objectives } \\
\text { and achieve virtual } \\
\text { student learning. } 5 . \\
\text { Correspondence between } \\
\text { the objectives and goals of } \\
\text { the virtual training course } \\
\text { with the organizational } \\
\text { structure (exploration, } \\
\text { prioritization, selection, } \\
\text { classification and } \\
\text { organization (sequential, } \\
\text { hierarchical, network or } \\
\text { hybrid)) the contents of } \\
\text { the virtual environment. } \\
6 . \text { Continuous updating of } \\
\text { virtual course according to } \\
\text { their nature, technological } \\
\text { changes in the area of } \\
\text { information technology } \\
\text { and communications } \\
\text { - ICT, and work skills } \\
\text { required for the area to } \\
\text { which the virtual training } \\
\text { environment belongs. }\end{array}$ & $\begin{array}{l}\text { Variables: 1. Focus } \\
\text { (s) Teaching (s) in } \\
\text { the virtual course. } 2 . \\
\text { Consistency between } \\
\text { (the) pedagogical } \\
\text { approach (s) and } \\
\text { curriculum design } \\
\text { e-learning course. } \\
\text { 3. The virtual course } \\
\text { clearly identifies the } \\
\text { target population } \\
\text { (or collective) } \\
\text { which is directed } \\
\text { e-learning course. } \\
\text { 4. Correspondence } \\
\text { between the } \\
\text { pedagogical } \\
\text { approach } \\
\text { and teaching } \\
\text { methodologies of the } \\
\text { e-learning course. }\end{array}$ & $\begin{array}{l}\text { Variable 1: Existence } \\
\text { of activities in the } \\
\text { virtual space for the } \\
\text { development of ethics, } \\
\text { cognitive, emotional, } \\
\text { communicative, aesthetic, } \\
\text { physical and socio- } \\
\text { political dimensions } \\
\text { related to the contents } \\
\text { of the virtual learning } \\
\text { environment. }\end{array}$ & $\begin{array}{l}\text { Variables: } 1 \text {. The } \\
\text { existence within } \\
\text { the virtual course } \\
\text { clear and concrete } \\
\text { specification } \\
\text { of how this is } \\
\text { going to assess } \\
\text { student learning. } \\
2 \text {. The degree of } \\
\text { correspondence } \\
\text { between the nature } \\
\text { of the virtual } \\
\text { course, teaching } \\
\text { methods and forms } \\
\text { of assessment of } \\
\text { student learning } \\
\text { virtually. } 3 \text {. The } \\
\text { concept of students } \\
\text { about justice and } \\
\text { fairness rates of } \\
\text { assessment of } \\
\text { student learning is } \\
\text { applied. }\end{array}$ & $\begin{array}{l}\text { Variables: } 1 \text {. The } \\
\text { existence of national } \\
\text { / international } \\
\text { employees in the } \\
\text { construction of virtual } \\
\text { course standards. }\end{array}$ \\
\hline
\end{tabular}




\begin{tabular}{|c|c|c|c|c|c|}
\hline Identification & Academy & Pedagogical-Didactic & Formative & Evaluative & Technological \\
\hline $\begin{array}{l}\text { Indicators: 1. Verifiable } \\
\text { information in the } \\
\text { trading platform of } \\
\text { the course on the } \\
\text { name and type of } \\
\text { educational institution } \\
\text { responsible for the } \\
\text { online course, approved } \\
\text { by the Ministry of } \\
\text { Education of the } \\
\text { country or responsible } \\
\text { and belonging to a } \\
\text { nation's education } \\
\text { system body. } 2 \text {. } \\
\text { Existence in the virtual } \\
\text { environment education } \\
\text { program name that } \\
\text { owns the virtual } \\
\text { course, as an academic } \\
\text { unit responsible for } \\
\text { the construction, } \\
\text { development, and } \\
\text { monitoring of virtual } \\
\text { course. 3. Trustable } \\
\text { information in the } \\
\text { virtual environment of } \\
\text { the Educational Project } \\
\text { to which belongs the } \\
\text { course or curriculum } \\
\text { structure (formal or } \\
\text { informal) which is part } \\
\text { of the course for virtual } \\
\text { learning. } 4 \text {. Existence in } \\
\text { Education online course } \\
\text { level (undergraduate, } \\
\text { graduate) that owns the } \\
\text { course. }\end{array}$ & $\begin{array}{l}\text { Indicators: } 1 \text {. The virtual } \\
\text { course is a document } \\
\text { (subdivision or program } \\
\text { content) where present } \\
\text { and explain the virtual } \\
\text { course. } 2 \text {. The virtual } \\
\text { course specifically } \\
\text { provides training profiles } \\
\text { to be achieved in students } \\
\text { through the development } \\
\text { of its objectives. 3. The } \\
\text { virtual environment has } \\
\text { objectives (general or } \\
\text { course) and specific to } \\
\text { student training. } 4 \text {. The } \\
\text { opinion of teachers and } \\
\text { students (separately) } \\
\text { on the clear definition } \\
\text { of the objectives of the } \\
\text { virtual course. } 5 \text {. Review } \\
\text { of educational and } \\
\text { professional experts in } \\
\text { the area to which the } \\
\text { virtual course on the } \\
\text { validity of content and } \\
\text { methods used in the } \\
\text { development of virtual } \\
\text { learning belongs. } 6 . \\
\text { Opinion students about } \\
\text { the organizational } \\
\text { structure of the } \\
\text { virtual environment. } \\
7 . \text { The virtual course } \\
\text { has a recording and } \\
\text { documentation of its } \\
\text { versions in the computer } \\
\text { center or academic unit } \\
\text { responsible for the virtual } \\
\text { environment. } 8 \text {. Opinion } \\
\text { teacher (computer and } \\
\text { the area of knowledge } \\
\text { to which the virtual } \\
\text { course belongs) on the } \\
\text { level of upgrade virtual } \\
\text { environment. (by topic } \\
\text { or thematic course units) } \\
\text { in terms }\end{array}$ & $\begin{array}{l}\text { Indicators: } 1 . \\
\text { Verifiable information } \\
\text { on the existence of } \\
\text { one or more types } \\
\text { of pedagogical } \\
\text { approaches } \\
\text { (with behavioral } \\
\text { orientation, } \\
\text { constructivist, } \\
\text { constructionist, etc ...) } \\
\text { in the development } \\
\text { of virtual course. } 2 . \\
\text { Definition level (of } \\
\text { the) focus (s) Teaching } \\
\text { (s) of the virtual } \\
\text { course. 3. Opinion } \\
\text { from an expert in } \\
\text { computer science } \\
\text { and education, on } \\
\text { the correspondence } \\
\text { between the } \\
\text { pedagogical } \\
\text { approach or various } \\
\text { optical pedagogical } \\
\text { and teaching } \\
\text { methodologies } \\
\text { developed through } \\
\text { the virtual course. } \\
\text { Verifiable } 4 . \\
\text { Information on } \\
\text { the correlation } \\
\text { between (the) focus } \\
\text { (s) Teaching (s) and } \\
\text { curriculum design } \\
\text { of virtual learning } \\
\text { environment, in the } \\
\text { event that the course } \\
\text { is part of a formal } \\
\text { curriculum structure. } \\
5 . \text { The grade of } \\
\text { correspondence } \\
\text { between the } \\
\text { pedagogical } \\
\text { approach of the } \\
\text { virtual course and the } \\
\text { group to which it is } \\
\text { directed. }\end{array}$ & $\begin{array}{l}\text { Indicators: } 1 \text {. Verifiable } \\
\text { information within } \\
\text { the virtual course of } \\
\text { learning activities that } \\
\text { promote comprehensive } \\
\text { e-Learning (development } \\
\text { of above dimensions) of } \\
\text { the students. }\end{array}$ & $\begin{array}{l}\text { Indicators: } \\
\text { 1. verifiable } \\
\text { information } \\
\text { within the virtual } \\
\text { environment and } \\
\text { to the course of the } \\
\text { evaluation form of } \\
\text { student learning; } \\
\text { specifying type of } \\
\text { evaluation, testing } \\
\text { or assessment } \\
\text { instrument (or short } \\
\text { assessment quiz, } \\
\text { midterm exam, final } \\
\text { exam, work, project, } \\
\text { lab etc.), rating } \\
\text { scale (quantitative } \\
\text { or qualitative), } \\
\text { percentage of } \\
\text { evaluation, date } \\
\text { of assessment, } \\
\text { estimated time } \\
\text { of evaluation and } \\
\text { subject matter } \\
\text { content of the } \\
\text { assessment. } \\
\text { 2. Review of } \\
\text { professionals in } \\
\text { education and } \\
\text { computer, teachers } \\
\text { and students of } \\
\text { the virtual course } \\
\text { on the degree of } \\
\text { correspondence } \\
\text { between the forms } \\
\text { of assessment } \\
\text { of learning per } \\
\text { student, the nature } \\
\text { of the virtual course } \\
\text { and teaching } \\
\text { methods through } \\
\text { which develops } \\
\text { the course. 3. The } \\
\text { opinion of students } \\
\text { about the level } \\
\text { of justice and } \\
\text { fairness with which } \\
\text { different types } \\
\text { of assessments } \\
\text { through the } \\
\text { development of } \\
\text { online course apply. }\end{array}$ & $\begin{array}{l}\text { Indicators: } 1 \text {. verifiable } \\
\text { information on the } \\
\text { use of standards } \\
\text { IMS- Instructional } \\
\text { Management System } \\
\text { in the construction } \\
\text { of virtual learning } \\
\text { environment. }\end{array}$ \\
\hline
\end{tabular}

\section{DISCUSSION OF THE RESULTS OF THE INVESTIGATION}

The operative indicators integrated into the System of management of the virtual learning have a support based on the Science of the Education, the Science of the Computation, and the Administrative Science applied to the eLearning. About the Science of Education, the indicators are based on the process in the essential educational categories such as education, pedagogy, didactics, teaching-learning process, assessment of student learning, and evaluation applied to virtual training. The indicators in relation to Computer Science contain the basic variables of software standards, hardware, computer networks, learning objects, and virtual communication processes necessary to be evaluated through the indicators to guarantee and improve the operation of the virtual platform. Recognizing the importance of platform development in terms of indicators such as Blackboard, Moodle (Pan, Wang, \& Luo, 2018), (Bourdoucen, 2018) It is difficult to find research that integrates the essential bases of virtual training with ICT represented by education-computingadministration.

The context for which the indicators were constructed and validated is an international coverage of the participation of judges from several continents with characteristics of different countries, languages, and virtual educational systems. It is of the utmost importance to recognize structures of quality indicators such as those related to the Distance Education and Training Council (DETC) (Stella \& Gnanam, 2004), 
the indicators of success in distance education in Australia (Martz, Reddy, \& Sangermano, 2004), or the indicators of countries of the European Union Spain (Peach, 2001), Portugal (Coutinho, 2007), or Italy (Pigliapoco \& Bogliolo, 2005); but they are indicators built for local contexts of countries.

The indicators of operation in virtual spaces are not only integrated to the representative model of the training process in eLearning but are bases for the continued actions of the virtual learning management system. This management system belongs to the area of Strategic Administrative Science (Romiszowski, 2018), (Ahlstrand, Lampel, \& Mintzberg, 2001), (Henderson, Henderson, Grant, \& Huang, 2018) specifically related to the prospective operation of the Virtual Educational Institution and its courses offered. Then, they are indicators that, based on the basic concepts of the theory of Education, are adapted in present time to the technological conditions of the training platforms, but are projected in actions of management, decision, and prospective of the virtual course and consequently of the virtual institution.

\section{FUTURE RESEARCH}

Operational indicators are the first component of Learning Management Systems in virtual spaces supported by ICT. Based on the preceding, the continuous research actions of the system are: i) Construction of management-operational indicators of Management Systems. These indicators interrelate the operation of the virtual course with the management of the units of the Virtual Educational Institution at the level of middle management commands. Then they are indicators of human resources necessary for virtual training, process indicators of academic programs and their virtual courses, and physical indicators at the level of technological resources necessary for the virtual education offer of the institution through the programs of eLearning ii) Design and construction of the management-decision indicators of the Virtual Educational Institution, which are built based on operational and management-operational indicators. These indicators are indicators of virtual education programs or courses, demand in eLearning, process, and result of the institution that offers virtual education, and are the indicators that interrelate with the indexes of the Ministry of National Education of the country, in order to comply with the preparation of human talent at the virtual level of a country education system at the service of society. iii) Integrate the indicators of the operative, management and decision layers representative of the virtual learning management system, justified by educational postulates (John Dewey (Davidson-Shivers, Rasmussen, \& Lowenthal, 2018), Kurt Lewin (McFarland, 2017), Malcon Knowles (Dawson, Burton, Bessette, \& Wright, 2018)) where the indicators are based on one or several educational postulates applied to virtual training with ICT.

\section{CONCLUSIONS}

- The indicators were developed based on the representative model of the training process in virtual spaces supported by ICT.

- The formal bases of the model integrate the Science of Education, the Science of Computing, and the Science of Administration, applied to the process of virtual signing.

- The 153 indicators designed are valid with a confidence level of $90 \%$ and an error of $10 \%$ having computerized validation values equal to 91.83 .

- A number of 106 indicators of the 153 correspond to the formative, evaluative and technological dimensions of the virtual learning management system. Therefore, about $70 \%$ of the indicators integrate the evaluation of virtual learning through virtual education platforms, which is the essence of the virtual training process.

- Finally, the operational indicators are based on their research horizon for the construction and validation of the management and decision indicators of the learning management systems in virtual spaces. 


\section{BIODATA AND CONTACT ADDRESSES OF THE AUTHORS}

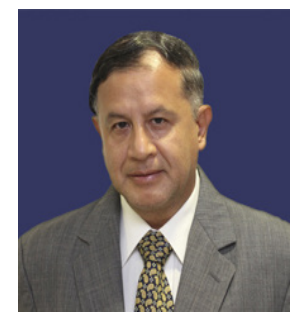

Dr. Jose CAPACHO, is an assistant professor at the Universidad del Norte (Barranquilla, Colombia). He did his doctoral studies at the University of Salamanca (2008) (Spain), in Learning Processes in Virtual Spaces. Professor Capacho earned his Master studies in Education at the Pontificia Universidad Javeriana (Colombia, 1996). His undergraduate was made in Systems Engineering in the Universidad Industrial de Santander - UIS (Colombia, 1982). Professor has over 30 years of service at Universidad del Norte. During this time, as Coordinator of the System Program, he has led projects of National and International Accreditation of the System Program (Universidad del Norte), with institutions such as the Colombian National Accreditation Council (NAC) $(1998,2005,2012)$; and the Agency Accreditation Board for Engineering and Technolgy (2003, 2005). As a teacher, he has participated in the renewal accreditation process of the System Program with ABET Accreditation International (2013, 2014, 2015).

Jose CAPACHO

Address: Deparment of Systems Engineering and Computer Science

Universidad del Norte, 080001, Barranquilla, Colombia

Phone: +573509279

Email: jcapacho@uninorte.edu.co

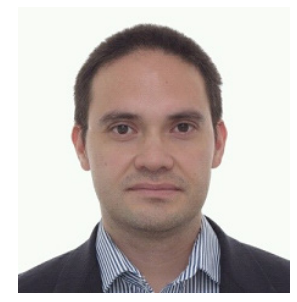

Dr. Miguel JIMENO, is an associate professor at the Universidad del Norte (Barranquilla, Colombia). He graduated as Systems Engineer from Universidad del Norte in 2002 and worked as a software engineer for several years. He then completed the Master of Science and Ph.D. in Computer Science at University of South Florida in 2007 and 2010 respectively. He has worked for 9 years as a professor for the Systems Engineering Department at Universidad del Norte. As a professor, he has participated in the renewal accreditation process of the System Program with ABET Accreditation International (2013, 2014, 2015).

Miguel JIMENO

Address: Deparment of Systems Engineering and Computer Science

Universidad del Norte, 080001, Barranquilla, Colombia

Phone: +57 3509694

Email:majimeno@uninorte.edu.co

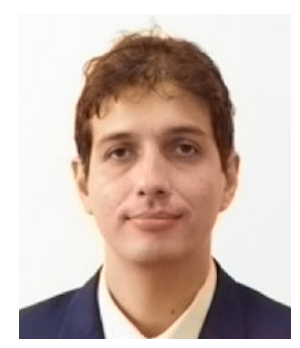

Dr. Augusto SALAZAR, is an assistant professor at the Universidad del Norte (Barranquilla, Colombia). He got this bachelor degree on System Engineering from La Universidad del Norte (CO) on 2003 and a Masters degree on Computer Science from National Chiao Tung University (TW) on 2012. Worked on the industry on Embedded System for a total of 9 years on companies such as Ericsson LMF (FI), Hitron Technologies (TW) and Proscend Communications (TW). For the past 6 years holds a position as an assistant professor on the department of System Engineering at La Universidad del Norte where covers courses on Introduction to programming, Computer Architecture, Embedded Systems and Mobile Applications. His research topics cover embedded system application on robotics, game anaytics, use of sensors on applications ubiquitous and intelligent systems for the detection of anomalies on the city roads.

Augusto SALAZAR

Address: Deparment of Systems Engineering and Computer Science

Universidad del Norte, 080001, Barranquilla, Colombia

Phone: +573509268

Email: augustosalazar@uninorte.edu.co 


\section{REFERENCES}

Ahlstrand, B., Lampel, J., \& Mintzberg, H. (2001). Strategy Safari: A Guided Tour Through The Wilds of Strategic Mangament. Simon and Schuster.

Ahn, J., Tejwani, R., Sundararajan, S., Sipolins, A., O’Hara, S., Paul, A., ... Huang, Y. (2018). Intelligent Virtual Reality Tutoring System Supporting Open Educational Resource Access. En International Conference on Intelligent Tutoring Systems (pp. 280-286). Springer.

Aldridge, S. C., \& Parker, M. L. (2018). Evaluating quality in fully online US university courses: a comparison of University of Maryland University College and Troy University. Revista Brasileira de Aprendizagem Aberta e a Distancia, 5.

Asoodar, M., Vaezi, S., \& Izanloo, B. (2016). Framework to improve e-learner satisfaction and further strengthen e-learning implementation. Computers in Human Behavior, 63, 704-716.

Assami, S., Daoudi, N., \& Ajhoun, R. (2018). Personalization criteria for enhancing learner engagement in MOOC platforms. En Global Engineering Education Conference (EDUCON), 2018 IEEE (pp. 1265-1272). IEEE.

Aziz, S., Mahmood, M., \& Bano, S. (2018). Total Quality Management: A Frame Work for Higher Education Institution. Journal of Research in Social Sciences, 6(1), 124-141.

Basogain, X., Olabe, M. Á., Olabe, J. C., \& Rico, M. J. (2018). Computational Thinking in pre-university Blended Learning classrooms. Computers in Human Behavior, 80, 412-419.

Bergeron, M. Z., \& Fornero, S. C. (2018). Centralized and Decentralized Approaches to Managing Online Programs. En Leading and Managing e-Learning (pp. 29-43). Springer.

Blieck, Y., Ooghe, I., Zhu, C., Depryck, K., Struyven, K., Pynoo, B., \& Van Laer, H. (2018). Consensus among stakeholders about success factors and indicators for quality of online and blended learning in adult education: a Delphi study. Studies in Continuing Education, 1-26.

Bordoloi, R. (2018). Transforming and empowering higher education through Open and Distance Learning in India. Asian Association of Open Universities Journal.

Bourdoucen, H. (2018). Human Factors Considerations in Mobile Learning Management Systems. En Interactive Mobile Communication Technologies and Learning: Proceedings of the 11th IMCL Conference (Vol. 725, p. 372). Springer.

Capacho, J. (2015). Representative Model of the Learning Process in Virtual Spaces Supported by ICT. Turkish Online Journal of Distance Education, 15(4), 75-89.

Capacho, J., Jimeno, M., \& Salazar, A (2018). A model to assess efficiency in e-Training for Significant Learning (e-TSL). LACCEI Latin American and Caribbean Conference for Engineering and Technology. Lima (Perú).

Castells, M. (2004). The network society A cross-cultural perspective. Edward Elgar.

Cheawjindakarn, B., Suwannatthachote, P., \& Theeraroungchaisri, A. (s. f.). A study on framework of educational technology and communication center to support online distance learning courses for higher education in thailand. Veridian e-Journal International Humanities, Social Sciences and arts, 10(5), 536-548.

Chitu, C., Cernian, A., \& Sgarciu, V. (2018). Education from Data-Driven eLearning's Perspective. eLearning \& Software for Education, 2.

Chua, A., \& Lam, W. (2007). Quality assurance in online education: The Universitas 21 Global approach. British Journal of Educational Technology, 38(1), 133-152.

Cohen, A., \& Holstein, S. (2018). Analysing successful massive open online courses using the community of inquiry model as perceived by students. Journal of Computer Assisted Learning.

Coutinho, C. P. (2007). Cooperative learning in higher education using weblogs: a study with undergraduate students of education in Portugal.

Davidson-Shivers, G. V., Rasmussen, K. L., \& Lowenthal, P. R. (2018). Foundations of Online Learning and Instructional Design. En Web-Based Learning (pp. 43-79). Springer.

Dawson, M., Burton, S. L., Bessette, D., \& Wright, J. (2018). Massive Open Online Courses and Integrating Open Source Technology and Open Access Literature Into Technology-Based Degrees. En Encyclopedia of Information Science and Technology, Fourth Edition (pp. 7898-7911). IGI Global.

de Leeuw, R. A., Walsh, K., Westerman, M., \& Scheele, F. (2018). Consensus on Quality Indicators of Postgraduate Medical E-Learning: Delphi Study. JMIR medical education, 4(1).

Ehlers, U.-D., \& Pawlowski, J. M. (2006). Handbook on quality and standardisation in e-learning. Springer Science \& Business Media. 
Garcia, R., Falkner, K., \& Vivian, R. (2018). Systematic literature review: Self-Regulated Learning strategies using e-learning tools for Computer Science. Computers \& Education, 123, 150-163.

Guerrero-Roldán, A.-E., \& Noguera, I. (2018). A model for aligning assessment with competences and learning activities in online courses. The Internet and Higher Education, 38, 36-46.

Hamalainen, R., Lanz, M., \& Koskinen, K. T. (2018). Collaborative Systems and Environments for Future Working Life: Towards the Integration of Workers, Systems and Manufacturing Environments. En The Impact of Digitalization in the Workplace (pp. 25-38). Springer.

Heinen, J., \& Peeters, H. (2018). Higher Police Education in the Netherlands. En Higher Education and Police (pp. 223-245). Springer.

Henderson, M., Henderson, L., Grant, S., \& Huang, H. (2018). Cognitive Engagement in Virtual Worlds Language Learning. En Authentic Virtual World Education (pp. 117-134). Springer.

Jackson, D. (2018). Challenges and strategies for assessing student workplace performance during work-integrated learning. Assessment \& Evaluation in Higher Education, 43(4), 555-570.

Jung, Y., \& Lee, J. (2018). Learning engagement and persistence in massive open online courses (MOOCS). Computers \& Education, 122, 9-22.

Marciniak, R., \& Sallán, J. G. (2018). Dimensiones de evaluacion de calidad de educacion virtual: revision de modelos referentes. RIED. Revista Iberoamericana de Educacion a Distancia, 21(1), 217-238.

Marshall, S., \& Flutey, J. (2018). The Virtual CSU: A Leadership Model for Universities Transitioning to Online, Open, and Distance Delivery. En Administrative Leadership in Open and Distance Learning Programs (pp. 63-83). IGI Global.

Martin, F., \& Kumar, S. (2018). Frameworks for Assessing and Evaluating e-Learning Courses and Programs. En Leading and Managing e-Learning (pp. 271-280). Springer.

Martins, J. V. G., de Menezes, R. M. T., de Lima Terçariol, A. A., Gitahy, R. R. C., \& Ikeshoji, E. A. B. (2018). The use of mobile devices in the college classroom: Project Method and mobile technologies in Higher Education. Revista Ibero-Americana de Estudos em Educaçao, 13(1), 500-519.

Martz, B., Reddy, V. K., \& Sangermano, K. (2004). Looking for indicators of success for distance education. Distance learning and university effectiveness: Changing educational paradigms for online learning, 144-162.

Masera, G. A., \& Ortiz, J. U. (2018). A Perfect world? Risks and Threats in the Information Society. International journal of research \& methodology in social science vol. 4, no. 1 jan-mar, 2018 Quarterly Journal ISSN 2415-0371, 4(1), 36-49.

McFarland, K. (2017). Entrepreneurship Education and Experiential E-Learning: A Literature Review. Developments in Business Simulation and Experiential Learning, 44(1).

McGrath, J. L., Taekman, J. M., Dev, P., Danforth, D. R., Mohan, D., Kman, N., ... Lemheney, A. J. (2018). Using virtual reality simulation environments to assess competence for emergency medicine learners. Academic Emergency Medicine, 25(2), 186-195.

McLoughlin, C., Patel, K. D., O'Callaghan, T., \& Reeves, S. (2018). The use of virtual communities of practice to improve interprofessional collaboration and education: findings from an integrated review. Journal of interprofessional care, 32(2), 136-142.

Mittelmeier, J., Rienties, B., Tempelaar, D., Hillaire, G., \& Whitelock, D. (2018). The influence of internationalised versus local content on online intercultural collaboration in groups: A randomised control trial study in a statistics course. Computers \& Education, 118, 82-95.

Nissen, V., \& Seifert, H. (2018). Digital transformation in business consulting-status quo in Germany. En Digital Transformation of the Consulting Industry (pp. 153-190). Springer.

Ouadoud, M., Chkouri, M. Y., \& Nejjari, A. (2018). LeaderTICE: a platforms recommendation system based on a comparative and evaluative study of free e-learning platforms. International Journal of Online Engineering (iJOE), 14(01), 132-161.

Outlaw, V., Rice, M. L., \& Wright, V. H. (2018). Building Quality Online Courses: Online Course Development Partnership and Model. En Teacher Training and Professional Development: Concepts, Methodologies, Tools, and Applications (pp. 309-331). IGI Global.

Pan, M., Wang, J., \& Luo, Z. (2018). Modelling Study on Learning Affects for Classroom Teaching/Learning Auto-Evaluation. Science, 6(3), 81-86.

Pástor, D., Jimenez, J., Gomez, O. S., \& Isotani, S. (2018). New Perspectives in Instructional Design using Semantic Web Technologies: A Systematic Literature Review. 
Peach, M. (2001). Globalization of education in Spain: From isolation to internationalization to globalization. Higher Education in Europe, 26(1), 69-76.

Pellas, N., Kazanidis, I., \& Fotaris, P. (2018). Facebook and Moodle integration into instructional media design courses: A comparative analysis of students' learning experiences using the Community of Inquiry (CoI) model.

Perez-Foguet, A., Lazzarini, B., Gine, R., Velo, E., Boni, A., Sierra, M., ... Trimingham, R. (2018). Promoting sustainable human development in engineering: Assessment of online courses within continuing professional development strategies. Journal of Cleaner Production, 172, 4286-4302.

Pigliapoco, E., \& Bogliolo, A. (2005). Global accessibility of higher education: Using ICT to build a worldwide campus. Proceedings of EISTA, 5.

Porras, J. T., Alcántara-Manzanares, J., \& García, S. R. (2018). Virtual platforms use: a useful monitoring tool. EDMETIC, 7(1), 242-255.

Rodriguez, C., Hudson, R., \& Niblock, C. (2018). Collaborative learning in architectural education: Benefits of combining conventional studio, virtual design studio and live projects. British Journal of Educational Technology, 49(3), 337-353.

Romiszowski, A. (2018). The future of E-learning as an educational innovation: Factors influencing project success and failure. Revista Brasileira de Aprendizagem Aberta e a Distancia, 2.

Sansone, N., Ligorio, M. B., \& Buglass, S. L. (2018). Peer e-tutoring: Effects on students' participation and interaction style in online courses. Innovations in Education and Teaching International, 55(1), 13-22.

Sarafzade, A., Bishop, P., Nagle, J., Tilden, G., \& Oettinger, M. (2018). Educational Proficiency Development and Assessment System. US Patent App. 15/580,198.

Scherer, R., Tondeur, J., Siddiq, F., \& Baran, E. (2018). The importance of attitudes toward technology for pre-service teachers' technological, pedagogical, and content knowledge: Comparing structural equation modeling approaches. Computers in Human Behavior, 80, 67-80.

Schophuizen, M., Kreijns, K., Stoyanov, S., \& Kalz, M. (2018). Eliciting the challenges and opportunities organizations face when delivering open online education: A group-concept mapping study. The Internet and Higher Education, 36, 1-12.

Soffer, T., Kahan, T., \& Livne, E. (2017). E-assessment of online academic courses via students' activities and perceptions. Studies in Educational Evaluation, 54, 83-93.

Soler, R., \& Sarsa, J. (2012). Integration of the Information and CommunicationTechnologies in the Teaching-Learning Processes: The Inclusive School. International Journal of Information and Education Technology, 2(5), 564.

Stella, A., \& Gnanam, A. (2004). Quality assurance in distance education: The challenges to be addressed. Higher education, 47(2), 143-160.

Stracke, C. M., \& Tan, E. (2018). The Quality of Open Online Learning and Education: Towards a Quality Reference Framework for MOOCs.

Tait, A. (2018). Open Universities: the next phase. Asian Association of Open Universities Journal.

Tawafak, R. M., Romli, A. B., bin Abdullah Arshah, R., \& Almaroof, R. A. S. (2018). Assessing the Impact of Technology Learning and Assessment Method on Academic Performance. EURASIA Journal of Mathematics, Science and Technology Education, 14(6), 2241-2254.

Thorne, M., \& Macgregor, C. (2018). Pedagogy and Learning for Sustainability in a Virtual World Scaffold. En Authentic Virtual World Education (pp. 9-23). Springer.

Uziak, J., Oladiran, M. T., Lorencowicz, E., \& Becker, K. (2018). Students' and Instructor's Perspective on the use of Blackboard Platform for Delivering an Engineering Course. The Electronic Journal of e-Learning, $16(1), 1$.

Yago, H., Clemente, J., Rodriguez, D., \& Fernandez-de-Cordoba, P. (2018). ON-SMMILE: Ontology Network-based Student Model for MultIple Learning Environments. Data \& Knowledge Engineering, 115, 48-67.

Zheng, Q., Chen, L., \& Burgos, D. (2018). Design Model for MOOCs in China. En The Development of MOOCs in China (pp. 149-165). Springer. 